\title{
Penanggulangan Miskonsepsi Menggunakan \\ Pendekatan Konflik Kognitif
}

\author{
Sapuadi $^{1 *}$, Muhammad Nasir ${ }^{2}$ \\ ${ }^{1}$ IAIN Palangka Raya, sapuadi@iain-palangkaraya.ac.id \\ 2IAIN Palangka Raya, nasir@iain-palangkaraya.ac.id
}

\begin{abstract}
ABSTRAK
Artikel ini merupakan kajian konseptual tentang pendekatan konflik kognitif sebagai alternatif perubahan miskonsepsi siswa dalam proses pembelajaran. Pendekatan konflik kognitif didasarkan teori perkembangan kognitif Piaget terutama tentang equilibration. Kajian dilakukan melalui library research. Kajian ini membahas tentang miskonsepsi dan penyebabnya, teori perkembangan kognitif Piaget sebagai dasar perubahan konsep siswa, dan pendekatan konflik kognitif untuk menanggulangi miskonsepsi siswa.
\end{abstract}

Kata Kunci: Miskonsepsi, Teori perkembangan Piaget, Equilibration

\begin{abstract}
This article is a conceptual study of the cognitive conflict approach as an alternative to changing student misconceptions in the learning process. The cognitive conflict approach is based on Piaget's theory of cognitive development, especially about equilibration. The study was conducted through a research library. This study discusses misconceptions and their causes, Piaget's theory of cognitive development as the basis for changing student concepts, and cognitive conflict approaches to overcome student misconceptions.
\end{abstract}

Keywords: Misconception, Piaget's theory of development, Equilibration

Article History:

Received : 29-09-2020

Revised : 08-11-2020

Accepted : 16-11-2020

Copyright (c) Sapuadi, Nasir

\section{PENDAHULUAN}

Penanggulangan miskonsepsi merupakan tantangan bagi guru
(Rowell, Dawson, \& Lyndon, 1990). Pembelajaran harus berorientasi, koheren dengan proses historis, 
sebagai perubahan konseptual dan metodologis dalam perspektif konstruktivis (Gil-Perez, \& Carrascosa, 1990). Sementara model pembelajaran yang dikembangkan berdasarkan pandangan kontruktivisme memperhatikan dan mempertimbangkan pengetahuan awal siswa. Beberapa penelitian dilakukan untuk menyelidiki miskonsepsi siswa (Goris \& Dyrenfurth, 2010; Puspasari, 2017; Sari, Djudin, \& Oktavianty, 2018 ; Budiarto, \& Setyaningsih, 2019) diantaranya miskonsepsi muncul dari pembelajaran siswa sebelumnya, baik di kelas atau dari interaksi mereka dengan dunia fisik dan sosial (Smith III, Disessa, \& Roschelle, 1994). Pengetahuan siswa yang diperoleh dari luar sekolah dipertimbangkan sebagai pengetahuan awal dalam sasaran pembelajaran, karena sangat mungkin terjadi miskonsepsi (Bell, 1993; Hasanah, Hidayat, \& Koeshandayanto, 2020).

Pendidik sangat dituntut untuk memahami bagaimana proses dan faktor yang menyebabkan terjadinya miskonsepsi siswa. Selain itu juga, pendidik perlu memahami bagaimana cara menanggulangi miskonsepsi tersebut dengan cara mengkaji leteratur yang berkaitan dengan teori pemerosesan informasi yang salah satunya adalah teori Piaget. Dalam paper konseprtual ini akan dibahas tentang penyebab miskonsepsi dan penanggulangannya ditinjau dari pendekatan konflik kognitif Piaget.

\section{METODE}

Kajian dilakukan melalui library research. Untuk menganalisis potensi pendekatan konflik kognitif sebagai alternatif penanggulangan miskonsepsi siswa dianalisis secara kualitatif deskriptif menggunakan teori Piaget.

\section{HASIL DAN PEMBAHASAN \\ Miskonsepsi dan Penyebabnya}

Miskonsepsi dikaitkan dengan ide-ide intuitif atau prasangka yang diperoleh sebelum pembelajaran sekolah (Driver, 1986). Dalam proses berpikir, siswa menyesuaikan konsep dan ide-ide baru yang mereka pelajari dengan kerangka berpikir (skema) yang telah mereka miliki. Siswa biasanya sudah membawa konsep-konsep sebelum mereka mengikuti pelajaran formal di sekolah. Kadang konsep-konsep yang mereka bawa itu tidak tepat dan tidak sesuai dengan pengertian para ahli yang disebut miskonsepsi 
(Suparno, 2013). Bentuk miskonseprsi dapat berupa konsep awal, kesalahan, hubungan yang tidak benar antara konsep-konsep, gagasan intuitif atau pandangan yang naif (Sumaji, 1998).

Miskonsepsi terjadi karena kesalahan dalam mengkonstruksi konsep berdasarkan informasi atau teori yang diperoleh oleh seseorang sebelumnya. Menurut teori kognitif Piaget bahwa proses belajar terdiri dari tiga tahapan, yakni asimilasi, akomodasi, dan equilibrasi (penyeimbangan). Asimilasi merupakan proses penyatuan (pengintegrasian) informasi baru ke struktur kognitif yang sudah ada dalam benak siswa. Proses asimilasi ini tidak akan menyebabkan perubahan atau pergantian skemata yang sudah ada pada diri siswa namun terjadi perkembangan skemata (Wadsworth dalam Suparno, 1997).

Akomodasi merupakan proses penyesuaian struktur kognitif ke dalam situasi yang baru, yaitu membentuk skema baru yang cocok dengan rangsangan yang baru atau memodifikasi skema yang ada sehingga cocok dengan rangsangan yang baru. Proses akomudasi ini

\section{Teori Perkembangan Kognitif Piaget sebagai Dasar Perubahan Konsep Siswa}

Jean Piaget (1936) dalam (Elkind, 1976; Ginsburg \& Opper, 1988) mengajukan teori tentang perkembangan kognitif anak yaitu 
kematangan, pengalaman, interaksi sosial, dan equilibrasi. Kematangan berkaitan dengan hasil perkembangan susunan syaraf seseorang. Pengalaman merupakan hubungan timbal balik antara diri seseorang dengan dunia luar. Interaksi sosial merupakan yaitu hubungan timbal balik seseorang dengan lingkungannya yang dapat mempengaruhi pola hidupnya. Sementara kemampuan seseorang untuk mengatur diri sendiri agar dia selalu mampu mempertahankan keseimbangan dan penyesuaian diri terhadap lingkungannya disebut equilibrasi.

$$
\text { Faktor pertama yang }
$$

mempengruhi perkembangan kognitif adalah pematangan. Teori Piaget mengusulkan bahwa hereditas spesifik melengkapi anak dengan berbagai struktur fisik yang memengaruhi perkembangan intelektualnya. Tahap perkembangan kognitif seseorang dapat dilihat seperti pada Tabel 1 .

Tabel 1 Tahap perkembangan kognitif anak menurut Jean Piaget (Wolfolk, 2009).

\begin{tabular}{cll}
$\begin{array}{lll}\text { Taha } \\
\mathrm{p}\end{array}$ & Usia & $\begin{array}{l}\text { Perkembangan } \\
\text { Kognitif }\end{array}$ \\
\hline Sens & $0-2$ & Bayi bergerak dari \\
orim & tahu & tindakan refleks \\
otor & $\mathrm{n}$ & instinktif pada saat \\
84 & &
\end{tabular}

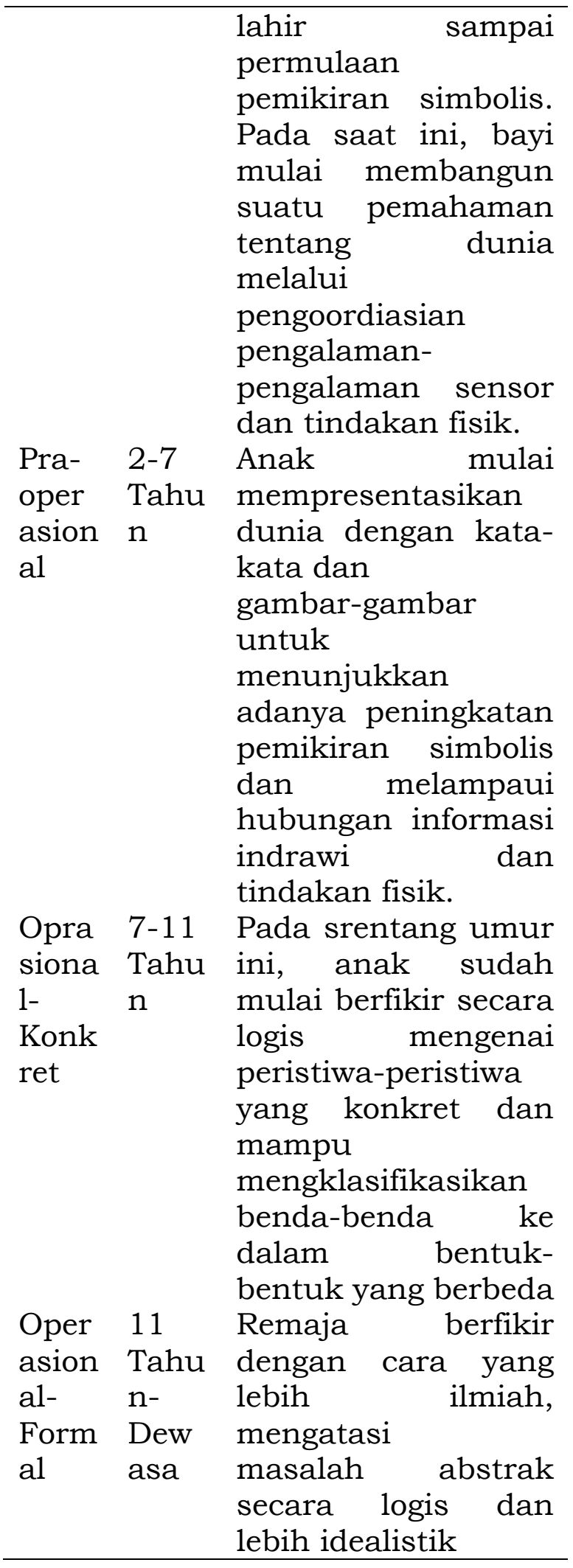

Faktor kedua pada perkembangan adalah kontak dengan lingkungan (pengalaman). Piaget merasa bahwa kontak dengan 
lingkungan mengarah pada dua jenis pengetahuan: fisik dan logika matematis. Pengalaman fisik mengarah pada pengetahuan yang bisa diamati. pengalaman logika matematis merupakan pengetahuan bukanlah hasil langsung dari mempersepsikan objek tetapi merefleksikan tindakan yang dilakukan pada objek.

Faktor

ketiga yang

mempengaruhi perkembangan kognitif adalah transmisi sosial. Transmisi sosial merujuk pada pengaruh budaya pada pemikiran anak. Penularan sosial dapat merujuk pada orang tua yang menjelaskan beberapa masalah kepada seorang anak, atau kepada seorang anak yang memperoleh informasi dengan membaca buku, atau kepada seorang guru yang memberikan instruksi di kelas, atau kepada seorang anak yang mendiskusikan pertanyaan dengan seorang teman, atau dengan seorang anak meniru model. Tentu saja, transmisi sosial pengetahuan mendorong perkembangan kognitif.

Faktor keempat yang mempengaruhi perkembangan adalah keseimbangan (equilibrium), yang dengan cara mengintegrasikan efek dari ketiga faktor lainnya. Equilibrium mengacu pada proses pengaturan diri anak yang dengannya ia semakin mencapai tingkat keseimbangan yang lebih tinggi selama perkembangan. Proses keseimbangan adalah tulang punggung pertumbuhan mental.

Bagi Piaget, perkembangan kognitif terdiri dari suksesi kesetimbangan bergantian dan ketidakseimbangan (disequilibrium). Setiap tingkat kesetimbangan berturut-turut mencapai bentuk pengetahuan yang lebih baik melalui penambahan dan reorganisasi elemen kognitif. Perubahan kuantitatif dan kualitatif ini menghasilkan hubungan baru, pemahaman baru, dan penyelesaian masalah tertentu, tetapi juga membuka kemungkinan pertanyaan dan masalah baru, ketidakseimbangan baru. Untuk mendamaikan stabilitas dan perubahan yang terjadi dalam perkembangan kognitif dan untuk menekankan aspek dinamis dari proses ini, Piaget menyebutnya sebagai mengoptimalkan keseimbangan (équilibration majorante). Mengoptimalkan keseimbangan adalah proses yang mengarah pada peningkatan kesetimbangan yang terjadi seiring dengan perkembangan. 
Piaget menjelaskan tiga jenis keseimbangan yang semuanya berkontribusi untuk mencapai keseimbangan antara orang dan lingkungannya. Yaitu keseimbangan antara seseorang dan objek atau peristiwa lingkungan, keseimbangan antara berbagai subsistem kognitif, dan keseimbangan antara sistem kognitif keseluruhan dan subsistem komponennya (Ginsburg \& Opper, 1988). Keseimbangan antara seseorang dan objek atau peristiwa lingkungan terjadi jika seseorang menemukan suatu objek, mengasimilasinya ke suatu skema, dan mengakomodasi skema itu ke objek tertentu. Jika skema itu sesuai maka terjadi equilibrium dan jika tidak maka akan terjadi disequilibrium. Seorang anak yang hanya memiliki skema untuk apel dan jeruk tidak akan kesulitan ketika menemukan contoh buah-buahan ini, tetapi akan berada dalam disekuilibrium ketika dihadapkan dengan nanas sebagai pengalaman pertamanya. Jenis keseimbangan ini tergantung pada interaksi antara seseorang dan lingkungannya, yaitu antara asimilasi dan akomodasi.

Jenis keseimbangan kedua adalah antara berbagai subsistem kognitif. Di sini, keseimbangannya adalah keseimbangan internal. Contoh ini dapat ditemukan saat terjadi kurangnya pemahaman masalah disebabkan oleh ketidakseimbangan karena perbedaan dalam kecepatan akuisisi berbagai kognitif subsistem. Asimilasi dan akomodasi juga terlibat dalam tipe keseimbangan kedua ini, tetapi mereka dilakukan secara internal dengan cara asimilasi timbal balik dan akomodasi dari berbagai subsistem kognitif.

Jenis keseimbangan ketiga adalah antara sistem kognitif keseluruhan dan subsistem komponennya, yaitu antara keseluruhan dan bagian-bagiannya. Sistem keseluruhan, dengan mengintegrasikan berbagai elemen, mengasumsikan berbagai properti sendiri yang tidak ditemukan dalam subsistem individual. Subsistem ini tidak berhenti eksis karena diintegrasikan, tetapi terus mempertahankan karakteristik spesifik mereka sendiri dan dengan demikian dibedakan satu sama lain.

Konsep keseimbangan mengacu pada keadaan keseimbangan atau harmoni antara setidaknya dua elemen yang 
sebelumnya berada dalam kondisi disekuilibrium. Mekanisme ekuilibrasi pada individu dipicu oleh gangguan sistem pengetahuan ketika 'celah' atau konflik dikenali dengan mencocokkan antisipasi yang dihasilkan oleh penerapannya, atau sebagian dari itu pada suatu objek atau peristiwa terhadap suatu interpretasi dari apa yang terjadi (Rowell, 1989). Sistem kognitif tidak pernah diam, ia terus berinteraksi dengan lingkungan. Sistem kognitif berusaha untuk menangani peristiwa lingkungan dalam hal strukturnya (asimilasi), dan dapat memodifikasi dirinya sesuai dengan tuntutan lingkungan (akomodasi). Ketika dalam ekuilibrium, sistem kognitif tidak perlu mendistorsi peristiwa untuk mengasimilasi mereka, dan tidak perlu banyak berubah untuk mengakomodasi peristiwa baru (Moessinger, 1978; Ginsburg \& Opper, 1988).

\section{Pendekatan Konflik Kognitif untuk Menanggulangi Miskonsepsi Siswa}

Pembentukan pengetahuan melalui pendekatan konflik kognitif dilandasi oleh filsafat konstruktivisme. Menurut aliran filsafat konstruktivisme bahwa bahwa pribadi seseorang sendirilah yang mengkonstruksikan pengetahuan. Secara garis besar, prinsip-prinsip konstruktivisme yaitu pengetahuan dibangun sendiri oleh siswa baik secara personal maupun sosial, transfer pengetahuan terjadi karena keaktifan siswa sendiri untuk menalar, terjadi perubahan konsep menuju pada diri siswa dari konsep sederhana menuju konsep yang lebih rinci dan lengkap dengan menggunakan metode ilmiah, dan guru hanya sebagai fasilitator (Suparno, 1997; Nana, 2018).

Pada pendekatan konflik kognitif, siswa dituntut berpartisipasi aktif dalam melakukan reorganisasi pengetahuan yang telah tersimpan dalam struktur kognitif. Terjadinya proses perkembangan struktur kognitif ditunjukkan oleh peristiwa adaptasi berupa asimilasi dan akomodasi. Perubahan konsep pada diri siswa dalam pembelajaran bisa terjadi jika terjadi proses asimilasi dan akomudasi (Posner dalam Suparno, 1997). Konsep-konsep awal yang telah ada pada diri siswa dihadapkan dengan informasi atau fenomena baru yang memicu terjadinya proses asimilasi untuk membentuk konsep baru namun 
tidak mengubah skemata yang sudah ada pada diri siswa. Sedangkan jika siswa membentuk konsep baru dengan menggantikan skemata yang sudah ada pada diri siswa maka terjadi proses akomodasi.

Menurut teori Piaget bahwa dalam otak siswa sudah ada informasi awal sebagai skemata, jika siswa memperoleh informasi baru dari luar dirinya (lingkungan) maka informasi baru tersebut akan disesuaikan dengan struktur kognitif (skemata) sehingga dapat menimbulkan konflik. Konflik kognitif ini ditandai dengan munculnya proses asimilasi dan akomodasi, yaitu perubahan konsep dengan membentuk struktur kognitif yang cocok dengan informasi baru tersebut. Perubahan konsep yang benar dapat dilakukan dengan pendekatan konflik kognitif sehingga pendekatan konflik kognitif dapat dipergunakan untuk mengembangkan pendekatan pengajaran yang secara khusus untuk perbaikan pemahaman konsep bagi siswa.

Pendekatan konflik kognitif dalam pembelajaran setidaknya dapat diterapkan melalui tiga fase (Niaz, 1995) yaitu, mengidentifikasi prakonsepsi siswa sebelum memulai pelajaran, membangkitkan situasi konflik atau pertentangan dalam struktur kognitif siswa, dan menyiapkan latihan untuk memantapkan konsep baru. Pendekatan konflik kognitif memiliki kelebihan, yaitu memperhatikan konsepsi yang salah pada diri siswa, memperhatikan hubungan antar konsep, melibatkan siswa secara aktif, membantu siswa dalam usaha memahami suatu konsep, menanamkan konsep baru dengan benar dan bisa bertahan lama (Limón, 2001; Tuqalby, Sutrio, \& Gunawan, 2017; Larasafitri, Sutrio, \& Gunawan, 2018; Kusuma \& Caesarani, 2019). Pendekatan konflik kognitif dapat diwujudkan dalam pembelajaran melalui pemberdayaan ketrampilan pemecahan masalah, ketrampilan pengambilan keputusan, ketrampilan berfikir kritis, dan ketrampilan berfikir kreatif (Yamin, 2008; Heryandi, 2018; Lestari, Gunawan, \& Kosim, 2019).

Struktur kognitif yang mendasari tingkah laku yang terorganisir dalam proses konflik kognitif diistilahkan oleh Piaget sebagai skema dan adaptasi. Skema (struktur kognitif) adalah proses atau cara mengorganisasi dan merespon 
berbagai pengalaman atau suatu pola sistematis dari tindakan, perilaku, pikiran dan strategi pemecahan masalah yang memberikan suatu kerangka pemikiran dalam menghadapi berbagai jenis tantangan dan jenis situasi. Sementara adaptasi (struktur fungsional) adalah untuk menunjukkan pentingnya pola hubungan individu dengan lingkungannya dalam proses perkembangan kognitif. Proses perkembangan kognitif melibatkan konflik di antara skema yang ada (disequalibrium). Adaptasi intelektual juga merupakan interaksi, atau pertukaran, antara seseorang dan lingkungannya dan melibatkan dua proses yaitu asimilasi dan akomodasi (Ginsburg \& Opper, 1988). Asimilasi dan akomodasi saling melengkapi, sedangkan organisasi dan adaptasi saling terkait. Misalnya, seseorang mengasimilasi peristiwa lingkungan ke dalam suatu struktur, dan orang mengakomodasi suatu struktur dengan tuntutan lingkungan yang akhirnya seseorang cenderung menuju keseimbangan dalam berpikir (equilibrium).

\section{KESIMPULAN}

Pendekatan konflik kognitif perlu dipertimbangkan oleh guru sebagai pendekatan untuk memperbiki miskonsepsi siswa. Konflik kognitif sebagai alternatif penanggulangan miskonsepsi sangat relevan dengan teori pemerosesan informasi Piaget tentang asimilasi dan akomudasi. Melalui pendekatan konflik kognitif diharapkan menanggunalangi pengetahuan awal (prakonsepsi) yang berpotensi menimbulkan miskonsepsi siswa.

\section{REFERENCES}

Bell, B. 1993. Children's Science Constructivism and Learning in Science. Geelong: Deakin University.

Budiarto, M. T., \& Setyaningsih, R. (2019). Konflik Kognitif Mahasiswa dalam Memahami Konsep Geometri Hiperbolik dan Elliptik. JUPITEK: Jurnal Pendidikan Matematika, 2(2), 6976.

Driver, R. 1986. Psicología cognoscitiva y esquemas conceptuales de los alumnos. Enseñanza de las ciencias: revista de investigación y experiencias didácticas, 4(1), 315.

Elkind, D. 1976. Child Development \& Education (p. 92). New York: Oxford University Press.

Gil-Perez, D., \& Carrascosa, J. 1990. What to do about science "misconceptions". Science Education, 74(5), 531-540.

Goris, T., \& Dyrenfurth, M. 2010. Students' misconceptions in 
science, technology, and engineering. In $A S E E$ Illinois/Indiana section conference

Ginsburg, H. P., \& Opper, S. 1988. Piaget's theory of intellectual development. Prentice-Hall, Inc.

Hasanah, N., Hidayat, A., \& Koeshandayanto, S. (2020). Pengaruh Strategi Konflik Kognitif Ditinjau dari Kemampuan Awal Siswa untuk Mengurangi Miskonsepsi pada Materi Gelombang Mekanik. Jurnal Pendidikan: Teori, Penelitian, dan Pengembangan, 5(5), 624-629.

Heryandi, Y. (2018). Problem Based Learning dengan Strategi Konflik Kognitif Meningkatkan Kemampuan Berpikir Kritis Matematis. Eduma: Mathematics Education Learning and Teaching, 7(1), 93-108.

Kusuma, J. W., \& Caesarani, S. (2019). Penerapan Pendekatan Konflik Kognitif Terhadap Pemahaman Konsep Matematis Siswa Di Smp Negeri 7 Kota Serang. JIPMat, 4(1).

Larasafitri, M. N., Sutrio, G., \& Gunawan, G. (2018). Pengaruh Pendekatan Konflik Kognitif Terhadap Penguasaan Konsep Fisika Peserta Didik. Jurnal Pendidikan Fisika dan Teknologi, 4(1), 66-71.

Lestari, P. A. S., Gunawan, G., \& Kosim, K. (2019). Model Pembelajaran Discovery Dengan Pendekatan Konflik Kognitif Berorientasi Pada Kemampuan Berpikir Kritis Peserta
Didik. Jurnal Pendidikan Fisika dan Teknologi, 5(1), 118-123.

Limón, M. 2001. On the cognitive conflict as an instructional strategy for conceptual change: A critical appraisal. Learning and instruction, 11(4-5), 357-380.

Moessinger, P. 1978. Piaget on equilibration. Human

Development, 21(4), 255-267.

Nana, N. (2018). Penggunaan Pendekatan Konflik Kognitif Untuk Remediasi Miskonsepsi Pembelajaran Suhu dan Kalor. In Prosiding SNPS (Seminar Nasional Pendidikan Sains) (pp. 8-14).

Niaz, M. 1995. Cognitive conflict as a teaching strategy in solving chemistry problems: A dialecticconstructivist perspective. Journal of research in science teaching, 32(9), 959970.

Puspasari, R. (2017). Strategi konflik kognitif (cognitive conflicts) dalam mengatasi miskonsepsi siswa. JP2M (Jurnal Pendidikan dan Pembelajaran Matematika), 3(1), 1-14.

Rowell, J. A. 1989. Piagetian epistemology: Equilibration and the teaching of science. Synthese, 80(1), 141162.

Rowell, J. A., Dawson, C. J., \& Lyndon, H. 1990. Changing misconceptions: a challenge to science educators. International Journal of Science Education, 12(2), 167-175.

Sari, K., Djudin, T., \& Oktavianty, E. (2018). Integrasi Remediasi Miskonsepsi dalam 
Pembelajaran Fluida Dinamis Menggunakan Pendekatan Konseptual Interaktif di SMA. Jurnal Pendidikan dan Pembelajaran Khatulistiwa, 7(5).

Smith III, J. P., Disessa, A. A., \& Roschelle, J. 1994. Misconceptions reconceived: A constructivist analysis of knowledge in transition. The journal of the learning sciences, 3(2), 115-163.

Sumaji 1998. Pendidikan Sains Yang Humanistis. Yogyakarta: Kanisius.

$\begin{array}{lr}\text { Suparno, P } & \text { Ponstruktivisme } \\ \begin{array}{l}\text { Kog7. } \\ \text { Pendidikan. } \\ \text { Kanisius. }\end{array} & \text { Fogyalsat } \\ \text { Dalam }\end{array}$

Suparno, 2013. Miskonsepsi \& Perubahan Konsep Dalam Pendidikan Fisika. Jakarta: Grasindo.
Tuqalby, R., Sutrio, S., \& Gunawan, G. (2017). Pengaruh Strategi Konflik Kognitif Terhadap Penguasaan Konsep Pada Materi Fluida Siswa Sman 3 Mataram Tahun Ajaran 2016/2017. Jurnal Pendidikan Fisika dan Teknologi, 3(1), 8-13.

Uno, H. B. 2010. Orientasi Baru Dalam Psikologi Pembelajaran. Jakarta: PT Bumi Aksara.

Yamin, M. 2008. Paradigma Pendidikan Konstruktivistik. Jakarta: Gaung Persada Press.

Yuliati, Y. 2017. Miskonsepsi Siswa Pada Pembelajaran Ipa Serta Remediasinya. Bio Educatio, 2(2), 279470.

Wolfolk, A. 2009. Educational Psychologi Active Learning Edition. Yogyakarta: Pustaka Pelajar. 
Al-Mudarris : Jurnal Ilmiah Pendidikan Islam

p-ISSN: $2622-1993$

Vol. 3, No. 1, Mei 2020, pp. 81-92

e-ISSN: 2622-1586 